\title{
Inheritance of coat colour in the cane Corso Italiano dog
}

\author{
Evžen Korec (iD, Matyáš Hančl, Marie Bydžovská, Ondřej Chalupa and Jana Korcová
}

\begin{abstract}
Background: The inheritance of different coat colours in the Cane Corso Italiano dog has not been described thus far. We analysed data from 23,271 dogs and bitches using the Cane Corso Italiano Pedigree Database. We are describing for the first time the coat colour segregation ratios in Cane Corso Italiano offspring arising from crosses between parents of all possible coat colour combinations.

Results: Segregation ratios that do not follow a Mendelian pattern suggest that additional genes are active in the determination of coat colour. Segregation ratios of offspring produced by parental crossing (male colour $\mathrm{A} \times$ female colour B) were compared with the ratios of offspring produced by reciprocal crossing (male colour B $\times$ female colour A) in all possible coat colour combinations.

Most of the segregation ratios were the same, but some segregation ratios in reciprocal crosses differed. This result suggests that at least one gene responsible for coat colour is located on a sex chromosome. The sex ratio was analysed in the offspring of all colour groups. A ratio of 1:1 was not confirmed in 8 colour groups by the chi-square test.
\end{abstract}

Conclusions: We described for the first time coat colour segregation ratios in Cane Corso Italiano dogs. Furthermore, we present the hypothesis that at least one gene responsible for coat colour is located on a sex chromosome.

Keywords: Cane Corso Italiano, Coat colour, Dog breed, Genetics, Sex chromosome, Inheritance

\section{Background}

Coat colour variations in different dog breeds have been a point of interest to breeders and researchers for a long time. The first papers concerning the coat colours of dogs appeared at the beginning of the twentieth century [1].

Little [2] and Winge [3] both published books suggesting a number of genes that could explain the inheritance of coat colour. Subsequently, many genes responsible for a dog's coat colour have been discovered and described during the past two decades [4-20]. However, a widely accepted nomenclature for gene names and symbols in domestic dogs does not exist; some genes were named historically by the scientists who first described them, and some genes were named according to their role in humans or a model organism. This was confusing for breeders as well as for scientists. A review by Kaelin and Barsh [21] summarized the issue of dog coat colour genetics, introduced a modified version of the historical nomenclature and identified

\footnotetext{
* Correspondence: director@zootabor.eu

Department of Genetics, ZOO Tábor, Dukelských hrdinů 19, 17000 Prague 7 , Czech Republic
}

12 coat colour loci in dogs. However, biological mechanisms are still unknown for some coat colour phenotypes.

Melanocortin 1 receptor (MC1R) was the first gene discovered by a molecular genetic analysis in dogs [22]. This gene can be identified with allelic locus E, and mutations in this gene commonly result in a distribution of eumelanin and pheomelanin. An important breakthrough was the discovery that pigment type-switching (black eumelanin and yellow pheomelanin) is controlled by three genes in dogs: Melanocortin 1 receptor (MC1R), Agouti signalling protein (ASIP) and $\beta$-Defensin 103 (CBD103) [23, 24]. These genes are associated with characteristic allelic influence (locus $\mathrm{E}$, locus $\mathrm{K}$ and locus A) for a dog's coat colour. Allelic dominance and the hierarchy of individual loci are summarized in Fig. 1 according to Kaelin and Barsh's review [21].

The Cane Corso Italiano (Fig. 2) is a breed with a great history; however the breed went almost extinct in the mid-twentieth century. Since then, the population of Cane Corsos has grown thanks to selective breeding. This breed was successfully accepted by the Italian 


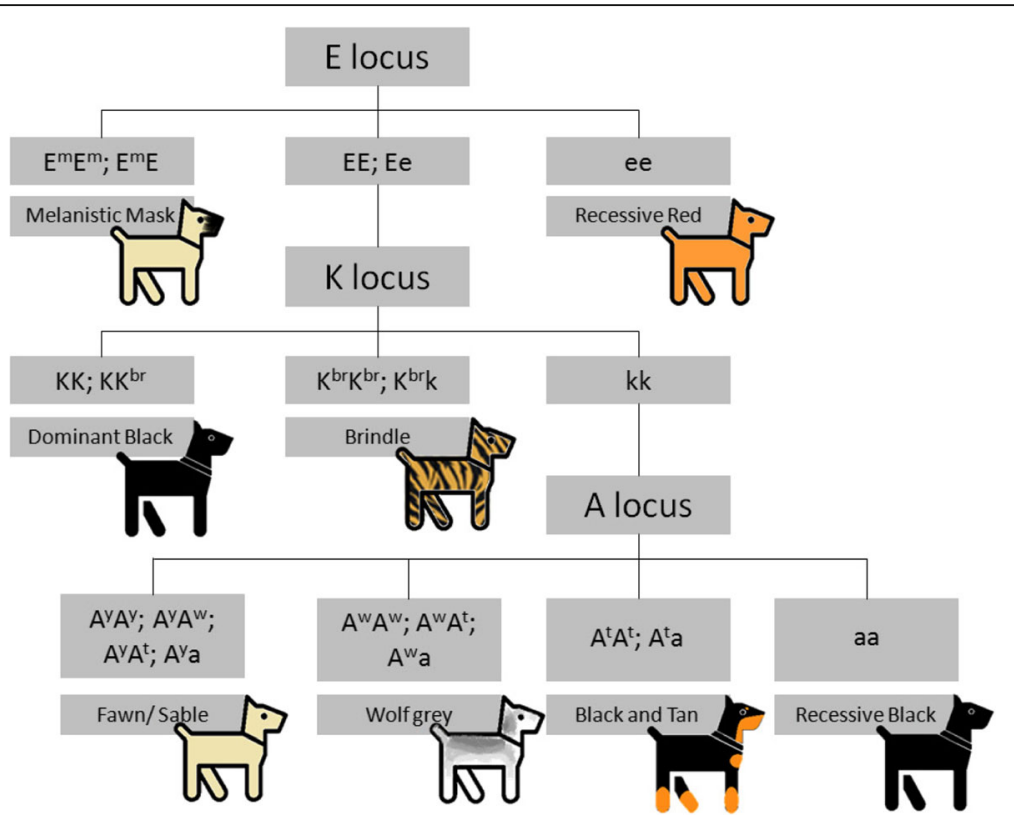

Fig. 1 Inheritance of the basic coat colour loci. Locus E affects the distribution of eumelanin and pheomelanin. In dogs, there are three alleles with specific dominance $\left(E^{\mathrm{m}}>E>e\right) . E^{\mathrm{m}}$ is responsible for melanistic mask and e is responsible for recessive red. The $\mathrm{K}$ locus is hypostatic for the E locus, and there are also three alleles with a specific hierarchy $\left(K>K^{b r}>k\right)$. The $K$ allele is responsible for dominant black and $K^{b r}$ is responsible for brindle colour. Locus $A$ has four alleles, and the dominance of these alleles is $A^{y}>A^{w}>A^{t}>a$. Allele $A^{y}$ is responsible for fawn or sable colour. Allele $A^{w}$ represents wild colouration, which is ancestral. Allele $A^{t}$ represents black and tan or saddle and tan colouration, and allele a is responsible for recessive black. Alleles $\mathrm{E}$ and $\mathrm{k}$ are wild-type, and coat colour is under the control of hypostatic loci

Kennel Club (ENCI) in 1994 and was fully recognized by the Federation Cynologique Internationale (FCI) in 2007.

The results of the first research on this breed were described by Korec et al. [25]. In most breeds, a relatively narrow range of colours are allowed within the standard, and in some breeds, all dogs have the same colour pattern. In the Cane Corso Italiano breed, the FCI standard allowed the following colours: black, black brindle, brindle, fawn, grey and grey brindle. The inheritance patterns of different coat colours in the Cane Corso Italiano has not been described so far.

\section{Methods}

Data collection

All data regarding the Cane Corso Italiano breed were obtained from the Cane Corso Italiano Pedigree Database

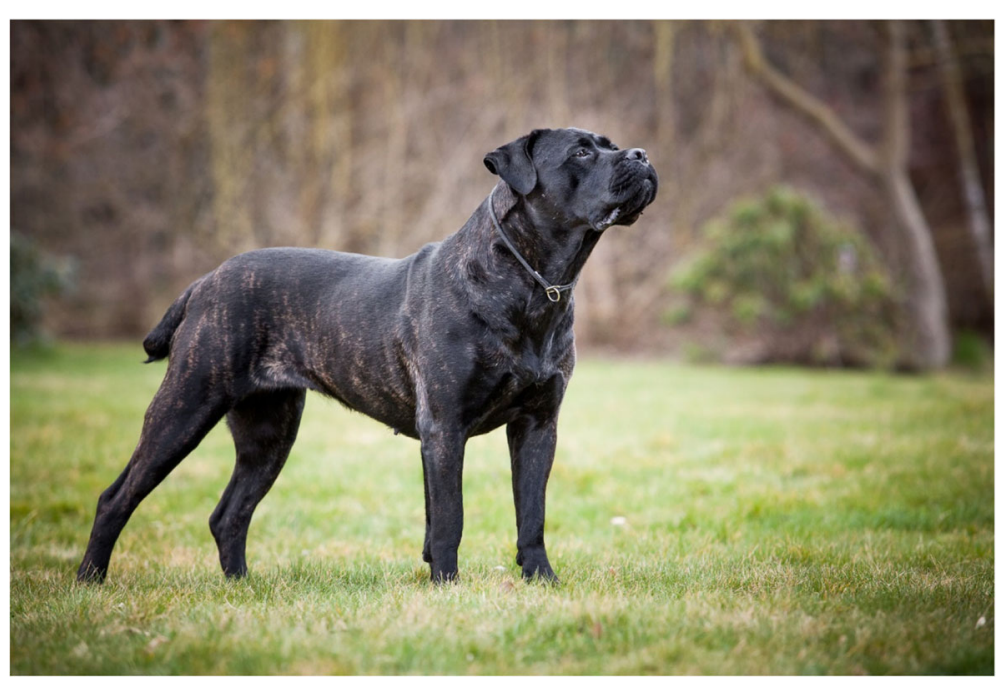

Fig. 2 Photograph of a Cane Corso Italiano dog (Koleta Atison, Evžen Korec's archive) 
[26] (www.canecorsopedigree.com/). Data collection was focused on the coat colour and sex of 82,169 individuals. Individuals without a complete data set were excluded from the analyses (71.7\%). Only data of litters with complete information about parents and offspring (28.3\%) were used for further analysis.

\section{Statistical methods}

For the statistical analysis, we used data from 23,271 individuals (dogs, bitches and offspring). The chi-square test [27] was used for statistical confirmation of segregation ratios. A $p$-value $<0.05$ was considered statistically significant.

\section{Results}

The main aim of this study was to identify the principles of inheritance of coat colours in Cane Corso Italiano breed. First, we attempted to verify whether the principles of Mendelian inheritance of the coat colour could be applied. Crosses between males and females of the same colour are summarized in Fig. 3.

Black is the most frequent coat colour in the Cane Corso breed. The segregation ratio of the offspring produced by crossing two black parents is summarized in Fig. 3a. Of the offspring, $71.6 \%$ were black, and $28.4 \%$ were other colours.
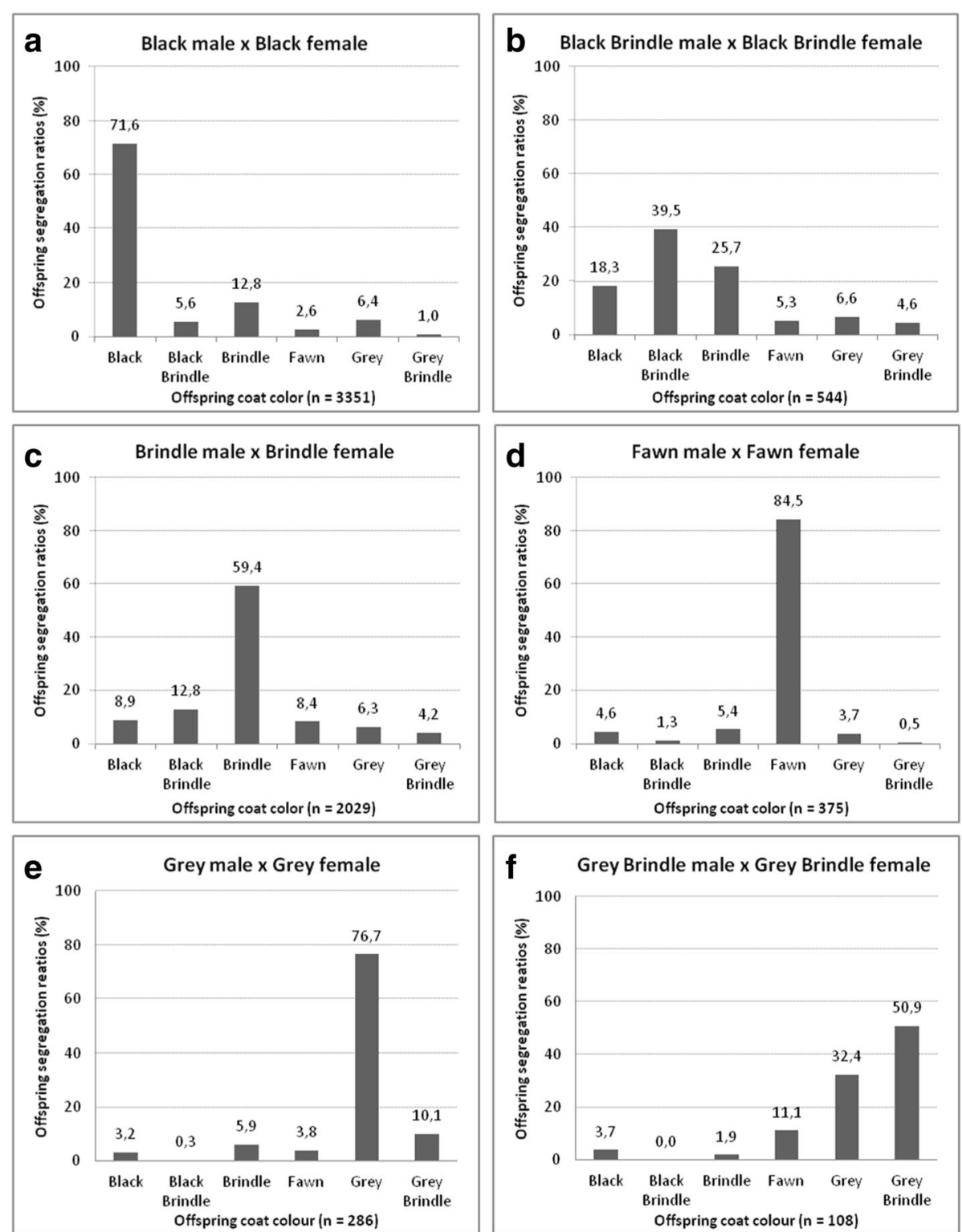

Fig. 3 Male and female crossing of the same colour in the Cane Corso breed. a crossing two black parents. $\mathbf{b}$ crossing two black brindle parents. c crossing two brindle parents. $\mathbf{d}$ crossing two fawn parents. e crossing two grey parents. $\mathbf{f}$ crossing two brey brindle parents 
Table 1 Offspring colour groups with sex ratios different than 1:1

\begin{tabular}{|c|c|c|c|c|c|}
\hline \multicolumn{2}{|l|}{ Parents } & \multicolumn{3}{|l|}{ Offspring } & \multirow{2}{*}{$\begin{array}{l}\text { Chi - square tes } \\
p \text {-value }\end{array}$} \\
\hline Male colour & Female colour & Colour & Number of males & Number of females & \\
\hline Brindle & Grey brindle & Brindle & 90 & 55 & 0.0037 \\
\hline Black & Brindle & Black & 524 & 615 & 0.0070 \\
\hline Black & Black & Black & 1141 & 1259 & 0.0160 \\
\hline Brindle & Brindle & Black brindle & 110 & 148 & 0.0180 \\
\hline Fawn & Black brindle & Brindle & 63 & 91 & 0.0241 \\
\hline Brindle & Black & Black & 488 & 560 & 0.0261 \\
\hline Black & Grey & Black & 159 & 198 & 0.0390 \\
\hline Black & Brindle & Black brindle & 61 & 86 & 0.0392 \\
\hline
\end{tabular}

Crossing two black brindle parents resulted in segregation of the offspring, where only $39.5 \%$ of the offspring were black brindles, $25.7 \%$ were brindles and $34.8 \%$ had other colours (Fig. 3b). Crossing two brindle parents resulted in $59.4 \%$ brindle offspring and $40.6 \%$ other-colour offspring (Fig. 3c). Crossing two fawn parents resulted in $84.5 \%$ fawn offspring and $15.5 \%$ other-colour offspring (Fig. 3d). Crossing two grey parents resulted in $76.7 \%$ grey offspring and 23.3\% other-colour offspring (Fig. 3e), and grey brindle parents produced $50.9 \%$ grey brindle offspring and $49.1 \%$ other colour offspring (Fig. 3f).

These results suggest that the inheritance of coat colour is much more complicated and that additional genes are involved. The segregation ratios of offspring produced by the parental crossing of all possible colour variations suggest that at least one gene responsible for coat colour is located on a sex chromosome. To verify this hypothesis, the sex ratio was analysed in offspring of all colour groups using statistically significant data. A ratio of $50 \%$ males and $50 \%$ females should be found if all genes responsible for coat colour are located only on autosomes. A ratio of 1:1 was found in most colour groups and was confirmed by the chi-square test. A sex ratio of 1:1 was not confirmed in 8 offspring colour groups by the chi-square test. These offspring colour groups are summarized in Table 1.

For brindle offspring, when brindle males were crossed with grey brindle females, 90 males and 55 females were produced. This result did not confirm a ratio of $1: 1$ using the chi-square test $(p=0.0037)$.

For black offspring, when black males were crossed with brindle females, 524 males and 615 females were produced. This result did not confirm a ratio of $1: 1$ using the chi-square test $(p=0.007)$. A ratio of 1:1 was not confirmed in an additional 6 offspring colour groups using statistically significant data (Table 1).

\section{Discussion}

We found that crossing black-, fawn- and grey-colour individuals (male and female of the same colour) resulted in a greater than $70 \%$ probability that offspring would present the same colour as their parents. On the other hand, the coat colour of offspring arising from crossing individuals of black brindle, grey brindle and brindle was much more dependent on the genetic background. Crossing parents of the same colours can produce a litter with multiple colour variations. This is an important finding because there is a demand for specific colours within the community of breeders.

The results of sex segregation ratios confirmed our hypothesis that at least one gene responsible for coat colour is located on a sex chromosome. It is possible that one of the control mechanisms or biochemical pathways controlling the expression of coat colour could be regulated by sex chromosomes. Our hypothesis is supported by the fact that a gene located on a sex chromosome determines orange colouring in cats. This gene is still unknown, but its effect on coat colouring has been known for decades [1,28].

In dog coat colour genetics, there are many unknown mechanisms that lead to the expression of some colour phenotypes other than the basic colours (for example, ticking, progressive greying and tweed phenotypes). Hypothetically, the intensity of fawn, red, brindle or grey colours could be affected by gene or genes that are still unknown.

\section{Conclusions}

We are the first to describe coat colour segregation ratios in Cane Corso Italiano dogs. Segregation ratios that do not follow a Mendelian pattern indicate that additional genes are active in the determination of coat colour. For the first time, we described that at least one gene responsible for a dog's coat colour is located on a sex chromosome. The genetics of coat colour in dogs is a very progressive research field and a popular scientific topic. 


\section{Abbreviations}

ASIP: Agouti signalling protein; CBD103: Canine beta-defensin 103; FCl: Federation Cynologique Internationale; MC1R: Melanocortin 1 receptor

\section{Acknowledgements}

We wish to thank all persons responsible for the Cane Corso Italiano Pedigree Database.

\section{Funding}

This project was fully funded by ZOO Tábor. ZOO Tábor provided funding in the form of salaries for all of the authors who are also employees of ZOO Tábor. There were no additional costs or paid services used in this study.

\section{Availability of data and materials}

All data used are from Cane Corso Italiano Pedigree Database [26] (www.canecorsopedigree.com).

\section{Authors' contributions}

EK conceived and designed the study. OC, MB and JK collected the data. MH analysed the data and performed the statistical analyses. EK wrote the manuscript. All authors read, revised, and approved the final manuscript.

\section{Ethics approval and consent to participate}

The conducted research is not related to the use of animals.

\section{Consent for publication}

Not applicable.

\section{Competing interests}

All authors declare no potential conflicts of interest with respect to the research, authorship, and/or publication of this article.

\section{Publisher's Note}

Springer Nature remains neutral with regard to jurisdictional claims in published maps and institutional affiliations.

Received: 2 August 2018 Accepted: 21 February 2019

Published online: 04 March 2019

\section{References}

1. Wright S. Color inheritance in mammals: IX. The dog-many kinds of white patterns found-albinism resembles that of other mammals in reducing red more than black-inheritance of black-and-tan requires further data-red and liver simple recessives. J Hered. 1918;9:87-90.

2. Little CC. The inheritance of coat color in dogs. Ithaca, NY: Comstock Publishing Associates; 1957.

3. Winge $\varnothing$. Inheritance in dogs: with special reference to hunting breeds Ithaca, NY: Comstock publishing associates; 1950.

4. Schmutz SM, Berryere TG, Goldfinch AD. TYRP1 and MC1R genotypes and their effects on coat colour in dogs. Mamm Genome. 2002;13:380-7.

5. van Hagen MAE, van der Kolk J, Barendse MAM, Imholz S, Leegwater PA, Knol BW, van Oost BA. Analysis of the inheritance of white spotting and the evaluation of KIT and EDNRB as spotting loci in Dutch boxer dogs. J Hered. 2004:95:526-31.

6. Kerns JA, Newton J, Berryere TG, Rubin EM, Cheng JF, Schmutz SM, Barsh GS. Characterization of the dog Agouti gene and identification of a nonagouti mutation in German shepherd dogs. Mamm Genome. 2004;15: 798-808.

7. Berryere TG, Kerns JA, Barsh GS, Schmutz SM. Association of an agouti allele with fawn or sable coat colour in domestic dog. Mamm Genome. 2005;16: 262-72.

8. Kerns JA, Candille SI, Berryere TG, Cargill EJ, Murph KE, Schmutz SM, Barsh GS. The Aaron B. Lerner lecture: genetics of melanocortin signalling: barking up a new tree. Pigment Cell Res. 2005;18(Suppl 1):2.

9. Philipp U, Hamann H, Mecklenburg L, Nishino S, Mignot E, Günzel-Apel AR, Schmutz SM, Leeb T. Polymorphism within the canine MLPH gene are associated with dilute coat colour in dogs. BMC Genet. 2005;6:34.

10. Clark LA, Wahl JM, Rees CA, Murphy KE. Retrotransposon insertion in SILV is responsible for merle patterning of the domestic dog. Proc Natl Acad Sci U S A. 2006;103:1376-81.
11. Rotschild MF, Van Cleave PS, Glenn KL, Carlstrom LP, Ellinwood NM. Association of MITF with white spotting in beagle crossed and Newfoundland dogs. Anim Genet. 2006;37:606-7.

12. Candille SI, Kaelin CB, Cattanach BM, Yu B, Thompson DA, Nix MA, Kerns JA, Schmutz SM, Millhauser GL, Barsh GS. A beta-defensin mutation causes black coat color in domestic dogs. Science. 2007;318:1418-23.

13. Karlsson EK, Baranowska I, Wade CM, Salmon Hillbertz NH, Zody MC. Efficient mapping of mendelian traits in dogs through genome-wide association. Nat Genet. 2007;39:1321-8.

14. Kerns JA, Cargill EJ, Clark LA, Candille SI, Berryere TG, Olivier M, Lust G, Todhunter RJ, Schmutz SM, Murphy KE, Barsh GS. Linkage and segregation analysis of black and brindle coat color in domestic dog. Genetics. 2007;176: 1679-89.

15. Schmutz SM, Berryere TG, Barta JL, Reddick KD, Schmutz JK. Agouti sequence polymorphism in coyotes, wolves and dogs suggest hybridization. J Hered. 2007;98:351-5.

16. Schmutz SM, Berryere TG. The genetics of cream coat colour in dogs. J Hered. 2007;98:544-8.

17. Clark LA, Wahl JM, Rees CA, Strain GM, Cargill EJ. Canine SINEs and their effects on phenotypes of the domestic dog. In: Genomics of disease. New York: Springer; 2008. p. 79-88.

18. Dreger DL. Schmutz SM. A new mutation in MC1R explains a coat color phenotype in 2 "old" breeds: saluki and afghan hound. J Hered. 2010;101: 644-9.

19. Clark LA, Tsai KL, Starr AN, Nowend KL, Murphy KE. A missense mutation in the 20S proteasome 32 subunit of great Danes having harlequin coat patterning. Genomics. 2011;97:244-8.

20. Dreger DL, Schmutz SM. A SINE insertion causes the black-and-tan and saddle tan phenotypes in domestic dogs. J Hered. 2011;102(Suppl 1):11-8.

21. Kaelin CB, Barsh GS. Genetics of pigmentation in dogs and cats. Annu Rev Anim Biosci. 2013;1:125-56

22. Newton JM, Wilkie AL, He L, Jordan SA, Metallinos DL, Holmes NG, Jackson IJ, Barsh GS. Melanocortin 1 receptor variation in the domestic dog. Mamm Genome. 2000;11:24-30

23. Candille SI, Kaelin CHB, Cattanach BM, Yu B, Thompson DA, Nix MA, Kerns JA, Schmutz SM, Millhauser GL, Barsh GS. A $\beta$-Defensin mutation causes black coat color in domestic dogs. Science. 2007:318(5855):1418-23.

24. Oguro-Okano M, Honda M, Yamazaki K, Okano K. Mutations in the Melanocortin 1 receptor, $\beta$-Defensin 103 and Agouti signaling protein genes, and their association with coat color phenotypes in Akita-Inu dogs. J Vet Med Sci. 2011;73(7):853-8.

25. Korec E, Chalupa O, Hančl M, Korcová J, Bydžovská M. Longevity of cane Corso Italiano dog breed and its relationship with hair colour. Open Vet J. 2017:7:170-3.

26. Cane Corso Italiano Pedigree Database. www.canecorsopedigree.com. Accessed 23 Mar 2017.

27. Plackett RL. Karl Pearson and the chi-squared test. Int Stat Rev. 1983;51:59-72.

28. Grahn RA, Lemesch BM, Millon LV, Matise T, Rogers QR, Morris JG, Fretwell N, Bailey SJ, Batt RM, Lyons LA. Localizing the X-linked orange colour phenotype using feline resource families. Anim Genet. 2005:36:67-70.

Ready to submit your research? Choose BMC and benefit from:

- fast, convenient online submission

- thorough peer review by experienced researchers in your field

- rapid publication on acceptance

- support for research data, including large and complex data types

- gold Open Access which fosters wider collaboration and increased citations

- maximum visibility for your research: over $100 \mathrm{M}$ website views per year

At $\mathrm{BMC}$, research is always in progress.

Learn more biomedcentral.com/submissions 